\title{
II. Meşrutiyet Döneminde Eşraf ve Köylü İlişkisi Üzerine Örnek Bir Olay: Çayırhan Köylüleri ile Hilmi Bey Arasındaki Arazi Anlaşmazlığı
}

\author{
Ercimet SARIAY $Y^{l}$
}

\section{Özet}

Osmanlı Devleti'nin Avrupa kapitalizmine kısmen de olsa eklemlendiği XIX. yüzyılın ortaları ile XX. yüzyılın başlarında, üretim ilişkileri ve toprak mülkiyeti konusunda, köklü denebilecek bir takım değişiklikler meydana gelmiştir. Özellikle, II. Meşrutiyet döneminde siyasal iktidara hâkim olan İttihat ve Terakki, iktisaden zor şartlar altında ezilen toplumsal grupların desteğine ihtiyaç duymuş, topraksız veya az topraklı köylüye toprak verilmesi, ucuz kredi temini gibi konularda bazı adımlar atmıştır. Ancak iyi niyetle atılan bu adımlar, özellikle kırsal kesimde gelir ve mülkiyet dağılımındaki adaletsizliği tam olarak gideremediği gibi savaş döneminde şartlar daha da kötüye gitmiştir. İttihat ve Terakki, savaş ortamında, yabancı sermayeli tarım şirketlerini tarım ve ticaret hayatının dışına itmeyi amaçlamıştır. Ancak bu süreçte, ülkede birçok harp zengini doğmuş, fakir durumda olan halk ve köylü daha da yoksullaşmıştır. Neticede bu durum, köylünün sosyal ve ekonomik durumunu düzeltmenin aksine, zengin ve büyük çiftliklere sahip bir sınıfı ortaya çıkarmış, tarımsal gelir dağılımındaki denge biraz daha bozulmuş, arazi ve mülkiyet konusundaki anlaşmazlıklar artmıştır.

$\mathrm{Bu}$ çalışmada, ekonomik ve sosyal bir mesele olarak toprak mülkiyeti konusunda, Ankara Vilayeti'ne tabi Nallıhan Kazasının Çayırhan Köyü ahalisi ile eşraftan Hilmi Bey arasında yaşanan arazi-mera anlaşmazlığ 1 üzerinde durulmuş, bu konuda, merkezi ve yerel yönetimin Hilmi Bey ile köylüye karşı tutumları değerlendirilmiştir. Çalışmada, konuyla ilgili arşiv belgeleri ilk elden kaynak olarak kullanılmıştır. Bunun yanı sıra Tanin Gazetesi muhabiri Ahmet Şerif Bey'in mektuplarının yer aldığı Anadolu'da Tanin isimli Osmanlı Türkçesiyle yazılmış kitaptan ve bazı araştırma eserlerinden yararlanılmıştır.

Anahtar Kelimeler: Çayırhan Köyü, Çayırhan Ahalisi, Hilmi Bey, Arazi, Mülkiyet.

\section{An Exemplary Case On The Relationship Between Gentry And Peasant During The $2^{\text {nd }}$ Constitutional Period: Land Dispute Between The Villagers Of Çayirhan And Hilmi Bey}

\begin{abstract}
In the mid- $19^{\text {th }}$ century and early $20^{\text {th }}$ century, when the Ottoman Empire was partially articulated in European capitalism, a number of fundamental changes occurred in the relations of production and land ownership. Particularly, the Committee of Union and Progress, which dominated political power during the $2^{\text {nd }}$ Constitutional Period, needed the support of the oppressed social groups under difficult economic conditions, has taken some steps on issues such as granting land to landless or less landed peasants and providing cheap loans. However, these steps taken in good faith did not completely eliminate the injustice of income and property distribution, especially in rural areas. On the other hand, in a war environment, the Committee of Union and Progress has aimed to push foreign agricultural companies out of the life of agriculture and trade. However, in this process, many war-rich people were born in the country and the poor folk and peasants became poorer. Eventually, this situation, rather than improving the social and economic situation of the peasant, has led to a class with rich and large farms, has further distorted the balance in agricultural income distribution, and has increased disputes over land and ownership.

In this study, on land ownership as an economic and social issue, the land-pasture dispute between the people of Çayırhan village and Hilmi Bey was discussed, in this respect, the attitudes of the central and local governments towards the villagers and Hilmi Bey were evaluated. In the study, archival documents related to the subject were used as a first hand source. In addition, it has been benefited from the book, Tanin in Anatolia, which is written in Ottoman Turkish, and which contains the letters of Ahmet Şerif Bey, who is the reporter of Tanin Newspaper, and from some research works.
\end{abstract}

Keywords: Çayırhan Village, Çayırhan People, Hilmi Bey, Land, Property.

1 Öğr. Gör. Dr., Aksaray Üniversitesi Atatürk İlkeleri ve İnkılap Tarihi Bölüm Başkanlığı, ercumentsariay@gmail.com 


\section{Giriş}

Osmanlı Devleti'nin Avrupa kapitalizmine kısmen de olsa dahil olduğu 19. yüzyılın ortalarından itibaren köylünün ürettiği artık ürüne devlet, eşraf, tefeci-tüccar sermayesi ve bir kısım yabancı sermayenin el koyma çabası, üretim ilişkileri ve toprak mülkiyeti yapısında bazı değişikliklere yol açmıştır (Cem 2017: 204). 20. yüzyılın başlarında ise, bu konuda daha radikal değişiklikler meydana gelmiştir. Bu süreçte İttihat ve Terakki yönetimi, kırsalda zor şartlar altında yaşayan köylüleri, ekonomik olarak desteklemek üzere bazı adımlar atmışır. Ancak iyi niyetle atılan bu adımlar, özellikle kırsal kesimde gelir ve mülkiyet dağılımındaki adaletsizliği tam olarak giderememiştir (Toprak 2016: 113-135). 1913 yılından itibaren toprakta mülkiyet anlayışının, daha çok büyük çiftçiler lehine düzenlenmiş olması bunun bir işaretidir. Dolayısıyla İttihat ve Terakki yönetiminin eşraf-köylü ilişkilerinde önemli bir yer tutan toprak politikasının, sosyal adalet ilkesine uygun olduğunu söylemek oldukça zordur. Uygulamaya konulan arazi kanunları, toprağın metalaşma sürecini, yani geçimlik olarak kullanılması yerine alınıp satılmasını hızlandırmış ve giderek dengesizleşen bir toprak mülkiyetini beraberinde getirmiştir (Ballı 2015: 6).

İttihat ve Terakki’nin, köylü politikası gereğince, köylü her alanda desteklenerek, toprak ağaları ile eşrafın elinden kurtarılmalıdır. Ancak, köylü ve toprak meselesi, bölgelerin sosyal ve iktisadi yapılarına göre farklılıklar gösterebilmektedir (Keyder vd. 2014: 28). Örneğin, iç bölgelerde, yerel eşrafa bağımlı ve boğaz tokluğuna çalışan ırgatlar olduğu gibi, tarımın kısmen ticarileştiği bölgelerde ücretli tarım işçilerini görmek mümkündür. İttihatçılar her iki grubun da çıkarlarına uygun küçük bazı adımlar atmışlardır (Ballı 2015: 5).

İttihatçıların, reformist denebilecek bir toprak siyasetine yöneldiklerini, bağımsız köylülüğü ve tarımda gelir dağılımını önemsedikleri söylenebilir. Bu bağlamda, arazi sahiplerinin hukuken geçerli olan tasarruf hakkı ihlal edilmeden köylülerin toprak sahibi olması, düşük faizle kredi alabilmelerinin sağlanması, toprak ağasının köylü üzerindeki baskısının önlenmesi amaçlanmıştır (Tunaya 2011: 99100). Ancak, topraksız ya da az topraklı köylüye toprak verilmesi meselesinin, ilerleyen süreçte gündemden düştüğü görülmüştür. Bunun temel nedeni, taşradaki eşrafin desteğini almak ve yerel örgütlenmede ondan yararlanabilmektir. Başka bir deyişle İttihat ve Terakki mclisteki gücünü korumak için seçimlerde eşrafin desteğini almak istemiştir (Ballı 2015: 6).

İttihat ve Terakki'nin yayın organı Tanin Gazetesi yazarı Ahmet Şerif Bey'in Anadolu gezileri, "köycülük akımının"2 somut ve çok önemli bir örneğidir (Aydın 2019: 29-30). Ahmet Şerif Bey'in gezi notları mektuplar halinde Tanin'de yayınlanmıştır. Anadolu'ya yönelik bu gezilerin amac1, Anadolu köylüsünü yakından tanımak ve ona göre politikalar üretebilmektir.

\footnotetext{
${ }^{2}$ İttihat ve Terakki'nin temel söylemlerinden biri olan köycülük fikri, II. Meşrutiyet Dönemi’nde yaygınlık kazanmıştır. Toplumsal tabanını genişletmek isteyen İttihat ve Terakki, köylüleri özellikle toprak ağalarına karşı korumak istemiş, bu minvalde, köylüye toprak dağıtılması, aşarın indirilmesi ve köylüye kredi sağlanması gibi konularda bazı adımlar atmıştır. Ayrıca köylünün eğitim ve refah düzeyinin yükseltilmesine de önem verilmiş̧ir.
} 
Birinci Dünya Savaşı sırasında tarımsal üretimin azalması ve iaşe sorununun ortaya çıkması, temel tüketim maddelerine olan talebi arttırmış, böylece talep Anadolu'ya kaymıştır. Sonuçta iç pazarda bir canlanma yaşanmış ve Anadolu kırsalında sermaye birikimi bir miktar artmıştır (Pamuk 2017: 166-171). Ancak savaş ortamında yaşanan sıkıntılar, köylünün sosyal ve ekonomik durumunu olumsuz etkilemiş, tarımsal gelir dağılımındaki dengeyi bozarak, arazi ve mülkiyet konusunda bazı anlaşmazlıklara yol açmıştır. Bu anlaşmazlıklardan biri de Ankara sancağına tabi Nallıhan kazasının Çayırhan köyünde yaşanmıştır.

\section{1. Çayırhan Köylüsü ile Hilmi Bey Arasında Yaşanan Arazi Meselesi}

Çayırhan köyü adını, Osmanlı sultanı I. Ahmet'in sadrazamlarından Nasuh Paşa'nın konaklamak amacıyla yaptırdığı handan almıştır. Dolayısıyla Çayırhan'ın dört yüz yıla yakın bir geçmişe sahip olduğu söylenebilir. (Şener 2001: 193-194). II. Meşrutiyet döneminde, Ankara sancağının kazası konumundaki Nallıhan'a bağlı olan Çayırhan köyü, Sakarya nehrinin kenarında olup, tahminen yüz kırk hane ve bin civarında bir nüfusa sahip bir yerleşim birimidir. Ankara'nın diğer köylerine nazaran, evleri oldukça bakımlı, arazisi verimli ve kıymetlidir. Köy ahalisinin refah düzeyi de komşu köylere oranla bir hayli yüksektir. Çayırhan köyü, idari bakımdan Nallıhan'a bağl1 olmasına rağmen, özellikle ticari açıdan Beypazarı ile daha yakın bir ilişki içinde olmuştur (Ahmed Şerif 1325/1909: 149). Ancak bu olumlu ortamın, meydana gelen arazi meselesi nedeniyle kısmen bozulduğu söylenebilir. Nitekim meselenin odağındaki isim olan ve II. Meşrutiyet meclisleri ile TBMM'de Ankara mebusu olarak görev yapan Hilmi Bey de (Mustafa Hilmi Çayırlıŏglu) Beypazarlı'dır. ${ }^{3}$

Osmanlı coğrafyasının değişik bölgelerinde özellikle de taşrada, arazilerin kullanımı konusunda eşraf ve köylüler arasında zaman zaman gerginlikler ve tartışmalar yaşanmıştır. Bu gibi durumlar, bir yandan asayişin bozulmasına, diğer yandan da hukuki ve ekonomik sorunlara yol açmıştır. Bu cümleden hareketle Çayırhan köyünde yaşanan hadisenin de benzer sonuçlar doğurduğu anlaşılmıştır. Çayırhan köyündeki arazilerin kullanımı konusunda yaşanan sıkıntılar, meselesinin tarafları olan Çayırhan köyü ahalisi ile eşraftan Hilmi Bey ve ailesini uzun bir süre meşgul etmiştir.

\footnotetext{
${ }^{3}$ Hilmi Bey (Mustafa Hilmi Çayırlıŏlu) 1867'de Ankara sancağına tabi Beypazarı kazasında doğmuştur. Babası Mustafa Bey, annesi Fatma Hanım'dır. Hali vakti yerinde çiftçi bir ailenin oğlu olan Hilmi Bey, çiftlik işleriyle uğraşırken eğitimi için hususi hocalardan ders almıştır. Daha sonra ticaretle uğraşmaya başlamıştır. II. Meşrutiyet yıllarında III. ve IV. Dönem (1914-1920) Meclis-i Mebusan seçimlerine katılarak Ankara'dan mebus seçilmiştir (Güneş 1998: 251; Yazıcı 2018: 21; Bilgen 2011: 42). İttihatçı ve ilerici olduğu için tutuklanarak Bekir Ağa koğuşunda hapis yatmıştır. Kürt Mustafa Paşa’nın başkanı olduğu divanı harpte yargılandıysa da zenginliğinin aileden geldiğini ispat etmesi sonucu beraat etmiştir (Haytoğlu 2017: 101). Hilmi Bey Milli Mücadele yıllarında Ankara'ya yabancı bandıralı gemilerle Bandırma üzerinden silah sevkiyatı yapmıştır. 23 Nisan 1920'de açılan ilk TBMM'de, Ankara milletvekili olarak görev yapmıştır (MMZC 1336/1920: 4). II. Dönemde de bu görevini sürdürmüş ve 1927 de TBMM'den ayrılmıştır. Aynı yıl Ankara'da vefat etmiştir. (http://tolunayozakaasml.meb.k12.tr/icerikler/tarihcemiz_4070655.html erişim tarihi.27.8.2019).
} 
Bunun yanı sıra bilhassa şikâyetlerin arttı̆̆ dönemlerde merkezi ve yerel yöneticiler de meseleye müdahil olmuşlardır.

Çayırhan köyündeki arazilerin tarım arazisi olarak mı yoksa mera olarak mı kullanılacağı konusu Çayırhan köyü ahalisi ile Hilmi Bey ve ailesini uzun bir süre meşgul etmiştir. Köylüler, arazinin vakıf arazisi olduğunu ve hayvanlarının burada otlatılmasının hayati bir önem taşıdığını iddia ederlerken, Hilmi Bey, arazinin kendi tapulu malı olduğunu, dolayısıyla tasarruf hakkının da kendisine ait olduğunu iddia etmiştir.

Çayırhan ahalisi, bahse konu olan arazinin vaktiyle Sevdaviyye ve Seyfiye Medreselerinin vakıf arazisi olduğunu, buralarda yirmi bin hayvan otlattıklarını, ancak vakfın mütevelli heyetinin haksız bir şekilde araziyi Hilmi Bey’e sattıklarını iddia etmişlerdir (Ahmet Şerif 1325/1909: 149-150). İddialar ve şikâyetler üzerine yapılan tahkikat neticesinde Ankara Vilayet İdare Meclisi’nde konuya ilişkin olarak bir karar verilmiştir. 14 Haziran 1904 tarihli kararda, Hilmi Bey ile Çayırhan ahalisi arasında ihtilafa neden olan arazi ve meraların sınırlarının belirlenmesi ve ahalinin elinde tarım ve hayvan otlatmak için yeterli arazinin olup olmadığının tahkiki için vilayet Mektubî Kalemi'nden Kasım Efendi, Defterî Kalemi'nden başkâtip Fehami Bey ile bir mühendisin görevlendirildiği belirtilmiştir. Bu kişilerin bölgede yaptıkları inceleme sonucunda, arazinin 149.996 dönümden ibaret olduğu, 1879 tarihli sened mucibince Zeki Efendi'nin tasarrufunda olduğu ve bu kişinin vefatıyla arazinin varislerine kaldığı ifade edilmiştir. Ayrıca arazide tasarruf sahibi olan Hacı Tevfik Efendi'nin mahdumları Mehmed Bahaddin, Mustafa Server, İbrahim, Ethem ve Ahmed Muhtar Efendiler tarafından arazinin bedeli karşılığında 2 Teşrinievvel 1312/14 Ekim 1896 tarihinde Hilmi Bey’e satıldığı belirtilmiştir. Köy arazisinin ziraata ve hayvan otlatmaya yeterli olduğu, dolayısıyla köylünün iddialarının abartılı olduğu belirtilmiştir (BOA, DH. MKT. 2701/95; Ahmed Şerif 1325/1909: 150). ${ }^{4}$ Çayırhan ahalisi ise, Hilmi Bey'in nüfuzunu kullanarak memurları baskı altına aldığını hatta tehdit ettiğini iddia ederek bu tür kararların geçerliliğinden şüphe duymuşlardır. "Hilmi Efendi'nin, eski devirde, olağanüstü bir etkisi vardı. Kazada, vilayette bulunan bütün memurlar kendisinden korkardl. İstanbul'da da o devirde en ileri gelen beyleri, paşaları elde etmişti. Bir dediği iki olmazdl. Hilmi Efendi'nin cesareti gittikçe arttl, tarlalarımızı zorla ele geçirdi. Her sene tarlaların vergisini biz veririz. Fakat o eker biçer, faydalanır. Ne yapalım o vaktin hükmünce biz de bazı kapılara çattık, efendiler bulduk. İstanbul'da, vilayette mahkemelerde uğraştık. Fakat nereye gitsek haksız çıkarılıyor, kovuluyorduk. Hilmi Efendi'nin hakkı ise, ilamlarla doğrulanıyor, destekleniyordu. Bizim vergisini verdiğimiz tapulu tarlalarımı için eline senet veriliyordu. Efendi, civarda silahlı adamlar gezdirir bizi tehdit ederdi. Meraya tarlalarımıza, odun kesmeye gidemez olduk. Bize her türlü hakareti reva

\footnotetext{
${ }^{4}$ Ahali ise bu konuda şunları söylemiştir: "Üç yüz on dokuz yllinda vilayetten bir heyet geldi. Bunların içinde, şimdi Ankara mebuslarından olan Kasim Efendi de bulunuyordu. Bize Sadaretten emir geldi, sizin meranizl, hududunuzu gelişstireceğiz dediler. Yüz kirk bin dönüm olan meranın güya doksan beş bin dönümün Hilmi Efendi'ye, içinde dörtte çiftlik bulunan kırk beş bin dönümünü bize ayırdılar. Fakat ne çıkar, bunlar zaten bizi aldatmak içindi. Özellikle heyet gelirken Beypazarı'nda ü̧̧ gün Hilmi Efendi'ye misafir olmuşlar. Kim bilir...".
} 
görürdü. Efendiden zarar gören yalnız biz değiliz. Civardaki yedi köyle, dört çiftlik de bitmektedir. Bunlar da tahminen üç bin nüfusla, dört beş yüz ev vardır" (Ahmed Şerif 1325/1909: 150-151). Köylüler burada II. Meşrutiyet öncesi döneme atıfta bulunarak bir nevi gücün ve baskının hukukun önüne geçtiğini ima etmişlerdir. Mesele, Meşrutiyet'in ilanına kadar belirsizliğini muhafaza etmiştir. Meşrutiyet'in ilanından sonra ortaya çıkan hürriyet havası içinde, Çayırhan ahalisi Hilmi Bey'in hukuksuz davranışlarından kurtulacaklarını umarak yeniden bazı girişimlerde bulunmuşlardır. Mağduriyetlerinin giderilmesi için bir yandan resmi makamlara dilekçe vermişler, diğer yandan da Hilmi Bey'in davarlarını meralardan çıkarmışlardır. Çayırhanlılar, 17 Şubat 1909 tarihli dilekçede, haklarını elde etmek için daha önce yaptıkları girişimlerden bir netice alamadıklarını, halkın köyden başka yere gitmek istediğini, mevcut yöneticilerin Hilmi Bey’in zulmünü görmezden geldiklerini, artık memlekette yeni bir idarenin kurulduğunu ve adaletin yerine geleceğinden emin olduklarını beyan etmişlerdir (BOA, BEO. 3505/262871; BOA, DH. MKT. 2733/278). ${ }^{5}$

2 Mart 1909'da, Defteri Hakânî nazırından Ankara Vilayetine gönderilen yazıda, mera arazisinin köylülere ait olduğunu kesin olarak tescilleyen resmi bir senedin olmadığı, ancak hayvan otlatılması için ayrılan bir arazinin de alınıp satılamayacağı açıç̧a ifade edilmiştir. Öte yandan Sadaret Mektubî Kaleminden Ankara Vilayetin'e yazılan yazıda, Defteri Hakânî nazırının yazısına atıfta bulunularak durumun bir an önce açıklığa kavuşturulması istenmiştir (BOA, BEO. 3505/262871). Dolayısıyla arazinin nasıl kullanılacağı ve kime ait olduğu konusu yine belirsiz kalmıştır.

Çayırhan ahalisinin girişimlerinden haberdar olan Hilmi Bey de hemen harekete geçerek merkezi hükümet nezdinde bazı girişimlerde bulunmuştur. Hilmi Bey, Çayırhan'daki arazinin tapulu malı olduğunu, hayvan otlatmak için köyde yeterli arazi bulunduğunu, köylülerin haksız bir şekilde arazisine müdahale ettiklerini ileri sürmüştür. Ankara valisi Ebubekir Bey de bu durumu Nallıhan

\footnotetext{
5 “...binaenaleyh memurin-i idareye vuku bulan şikayatımızın semeresiz bırakılmasına rağmen Nallıhan kazası mahkeme-i hukukuna vaki olan müracaatımız üzerine icra kllınan muhakeme esnasında irad-ı inba eylediğimiz her dürlü mudafaa'ne-i kanuniye ve dalaile rağmen mumaileyh Hilmi Efendi'nin mera-yı mezkûru bir kismını mütevelliden satın ald, buna mukabil Defteri Hakani Nezareti'nden mahreç kuyud-l resmiyede mumaileyhin kati surette tasarrufa hak ve selahiyeti olmadı̆̆ ve ba-husus böyle kurra ahalisine mahsus meralara hiçbir şahsın müdahale ve mu'arazasının arazi kanunnamesi micibince caiz görülemeyeceğinin tasrih buyurulduğu mudafaaten dermiyan edilmişken hakkı sarihimiz bundan üç sene mukaddem efrad-ı ahaliye abad ve ecdatlarından intikal idegelmiş birçok mezra' zalimen ahz-l merkume teslim kılınmışdı. ....istidanamemizde mumaileyhin zulmiyesine bir dakika evvel nihayet virilmesi esbabının istikbali arz ve istimdad idilmişdi. Maziye nisbet olunmayarak bu gibi umuma aid meraların her ne suretle zabt idilmiş olursa olsun hemen bil-istirdad eshabına iadesi hususuna müsaraat kılınmasına dair ittihaz buyurulan kararı ahir mucibince emsali hakkında Şura-yı Devletçe mazbatalar tanzim ve mahaline tebli' kılınmakda olduğu ve merkumun vilayetçe haiz olduğu nüfuz ve vali-i hazıra her husul-ı takribi bi tarafane icra-yl tahkikat ve kuyud-u hakani istizaha hacet bırakmayacak derecede vazıh ve aşikar iddüğünden iş bu istidanamemizin dahi müşarünileyhaya havalesiyle defteri hakani nezaretinden ber-vech-i ma'ruzu istihraç ve istihsal idilecek kayda tevfiken bir karar-l kat'iye rabıta ve icra hukukiyemizin iade itdirilmesi bu suretle yedi yüz elli nüfusun kurtarllması istida ve istirham olunur...".

Ankara Vilayeti Dâhilinde Nallıhan Kazası Çayırhan Karyesi Ahalisi Umumiyesi Namına: Muhtar Derviş ve Bir Aza.
} 
kaymakamına bildirmiştir (BOA, BEO. 3521/264074; BOA, DH. MKT. 2701/95). ${ }^{6}$ Buna karşın köylü şikâyetini sürdürmekle birlikte Dâhiliye Nazırı Talat Bey'in Hilmi Bey'den yana tavır koyması köylüyü büsbütün karamsarlığa itmiştir. "Hilmi Efendi hâlâ istediğini yaptyor, nereye gitse sözü dinleniyor. Pek vicdanl, namuslu bir kimse olduğunu işittiğimiz, kendisini büyük bir sevgiyle sevdiğimiz Dâhiliye Nazırı Talat Bey bile bu konuda bizi düşünmüyor, haksız çıkarıyor. Verdiği emirlerde, meranın Hilmi Efendi'ye teslimini, hayvanlarının meraya sokulmasını bildiriyor. Ĕger jandarma yetmezse diğer yerlerden de getirilerek kesin olarak bunun yerine getirileceğini yazlyor. Biz ise bu zamanda büyük ümidler besliyorduk. Şimdi ne yapacağız” (Ahmed Şerif 1325/1909: 151-152).

Çayırhan ahalisi, bu durumdan kurtulmak için kaymakamlığa bir dilekçe vererek mallarını mülklerini terk edip Kastamonu'ya göç etmek istemişlerdir (BOA, DH. MKT. 2831/37).

Buna rağmen, son çare olarak aralarından iki kişi seçip, Mudurnu kazasına göndermişler, oradan hükümete çekecekleri telgrafın sonucunu beklemeye başlamışlardır. Bunun sebebi Hilmi Bey'in Beypazarı ve Nallıhan'daki telgraf memurlarını baskı altında tutmasıdır. Bu esnada kolluk kuvvetlerinin köylüye kötü davranması, köylüyü daha da zor bir durumda bırakmıştır (Ahmed Şerif 1325/1909: $152-153){ }^{7}$

8 Şubat 1910 tarihinde, Dâhiliye Nezareti'nden Ankara vilayetine gönderilen yazıda, Çayırhan ahalisinin Hilmi Bey'in zulmünden mustarip oldukları, daha önce men edilmesine rağmen hayvanlarını meraya soktuğu ve kanunun gerektirdiği biçimde sorunun çözülmesi istenmiştir (BOA, DH. MKT. 2733/28). Buna rağmen sorunun çözüldüğ̈̈nü söylemek oldukça zordur.

$\mathrm{Bu}$ süreçte, sorunu köylülerle paylaşan ve onların söylemlerine kulak veren Tanin Gazetesi yazarı Ahmet Şerif Bey, hükümetin her daim köylünün yanında olduğunu, meselenin hukuk çerçevesinde çözümlenmesinin önemli olduğunu, aksi halde davranılması halinde köylünün asi duruma düşebileceğini ve hükümetle karşı kaşıya kalabileceğini belirterek, Çayırhan ahalisini teskin etmeye çalışmıştır (Ahmed Şerif 1325/1909: 154). ${ }^{8}$ Köylüler, Ahmet Şerif'in tavsiyelerini can

\footnotetext{
6 “...tapulu mülküme tecavüz idenlerin müdahalesi dört mahdır ki men' idilemedi. Kanunun sarahatine karşı hükümet alenen izharı aciz idiyor. Malım ayaklar altına itilüb gidiyor...”.

7 “...bu iş için zaptiyeler gelir, birç̧ok kişiyi alarak Nallihan'a götürürler. Geçen gün on iki kişi götürdüler. Müstantik bunlara sordu. Hapis edecek kadar bir kabahatleri yokmuş ki bir şey yapamad. Fakat hakimin, sen tevkif kararı ver, korkma be tasdik edeceğim dediğini kulağımızla işittik. Müstantik cesaret edemedi, savuştu. Hacı Efendi'nin Mustafa ile Selim oğlu Mahmud kahvehanede otururken teğmenin emri üzerine, bir zaptiye gelerek bunları ald, hapishaneye attılar. Tamam kırk sekiz saat içeride kaldılar. Diğer arkadaşlar valiye telgraf çektiler. İki gün sonra hapishaneden çıkarıldılar. Evvelki gün, onbaşı yanında dört zaptiye olduğu halde geldi. Karşılarına köyün kadınları, çocukları çıktı. Jandarmalar, Hilmi Efendi'nin hayvanlarını meraya sokmak istediklerinden buna engel olmak istiyorlardı. Bu sırada, onbașı ağıza alınmayacak en fena sözlerle kadınlara sövdü. Nizam Mustafa'nın ve Berber oğlu İbrahim'in kadınların tüfenk dipçiğiyle dövdü. Sofu oğllu Kerim'in yedi sekiz yaşlarındaki kizının üzerine hayvanını sürdü. Çocuk hayvanın altında kaldıysa da Allah'ın inayetiyle bir şey olmadı. Onbaşı, Hilmi Efendi'nin davarlarının meraya girmesi için irade-i seniyye olduğunu söylüyordu...".

8 "Bu günkü hükümetin en çok kendi iyiliklerine çalıştığını, Hilmi Efendi değil, kim olursa olsun hiçbir kimsenin haksız müracaatlarına kulak asılamayacağını, fakat onun da bir hakkı olmasa ve hükümet bunu anlamasa öyle
} 
kulağıyla dinledikten sonra aralarında meseleyi bir kez daha tartışmışlardır. Neticede, mera meselesinde bazı tavizler verebilecekleri ortaya çıkmıştır. Ahmet Şerif, köylünün kaymakamı sevdiğini, eğer kaymakam köye gelir de köylüleri ikna ederse hem hükümetin, hem köylünün hem de Hilmi Bey'in isteğinin yerine geleceğine inanmıştır (Ahmed Şerif 1325/1909: 156). ${ }^{9}$ Ahmed Şerif'in tavsiyelerinin köylü üzerinde olumlu bir etki bıraktığı söylenebilir. Kayıtlara baktığımızda, meselenin 1916'ya kadar gündemden düşmüş olması buna işaret etmektedir. Tabi bu arada, Hilmi Bey'in Ankara mebusu olarak Meclis-i Mebusan'da yer aldığını da unutmamak gerekir. Hilmi Bey'in seçimler esnasında köylüye daha yakın olmak ve mesele çıarmamak için daha dikkatli davrandığını söylemek mümkündür.

1916'da arazi meselesinin farklı bir boyuta taşındığı kayıtlardan anlaşılmaktadır. Hilmi Bey’e ve ailesine ait arazide yer alan çiftlikteki ambarlarda bulunan tohumluk buğdaya kaymakam Necmullah? Bey tarafından el konulması ve ambarların mühürletilmesi, Hilmi Bey ve ailesinin şikâyetine neden olmuştur (BOA, DH. İ. UM. 98/1). ${ }^{10}$ Kaymakamın bunu ne sebeple yaptırdığına dair belgelerde her hangi bir bilgi mevcut değilse de savaş şartlarının getirdiği kıtlık ve buğday ihtiyacının buna sebep olduğu söylenebilir. Dâhiliye Nazırı Talat Bey, Hilmi Bey’in şikâyeti üzerine Ankara Valisi Reşit Bey’e 9 Aralık 1916 tarihinde çektiği telgrafta ambarların derhal açılarak tohumluğun Hilmi Bey'in ailesine teslim edilmesini ve kaymakamın neden böyle bir tasarrufta bulunduğunun tahkik edilmesini istemiştir. Bunun üzerine Vali Reşit Bey, kaymakama Talat Bey’in emrini bildirmiştir. Kaymakam da emre uyarak ambarları açtırmıştır. (BOA, DH. İ. UM. 98/1). ${ }^{11}$ Ancak kaymakam merkezi hükümetin gözünden düşmüştür. Talat Bey, Ankara valisi Reşit Bey’e çektiği telgrafla, Kaymakamın görevini layıkıyla yerine getiremediğini, dolayısıyla görevden alınması

emirler vermeyeceğini söyledim. Hele köylülerin hükümete karşı gelmek, onun çalışmalrını zorlaştırmak isteyişleri pek yanlış olduğunu, böyle yapınca kendilerini seven ve düşünen hükümetin köylüye düşman olacağını anlayacakları bir dille ilave ettim”.

9 "Yavaş yavaş mantıklı düşünce, duygulara üstün geldi ve hayvanlar şu hududdan ileri geçmesin, filan yerlerdeki tarlalarımızda bizi serbest bıraksın gibi bazı kayıtlar ileri sürerek, esas kabul edilmiş, artık hükümet memurlarının yaptıklarına karışmamak kararlaştırılmıştı. Köylüler, fedakârlık etmiş, haklarından vazgeçmiş gibi üzüntülü, elemli görünüyorlardı. Yarın sabah, Nallıhan'a giderek kaymakama ve buradaki zabita memuruna durumu bildirecekler, yirmi beş mevkuhun tahliyesini istidaa'ideceklerdi"”.

${ }^{10}$ Hilmi Bey'in şikâyet babında Dâhiliye Nezareti'ne gönderdiği telgrafta şu ifadelere yer verilmiştir. “Bendeleri Beypazarı'nda işletmekte olduğum çiftlik ve sair arazide senevi beş altı bin kile tohum zira've on süvari ă̆nam beslerim. İs bu çiftlik ve arazinin zira've idaresiyle beş yüz nüfus istihdam iderim. Hasadda dahi bu mikdar iki misli olur. Şu hal mahallince herkesçe malum iken kaza-yı mezkûr kaymakamı Necmullah? Bey bilhassa şu zaman-ı harbide emri ziraat gerek faide-i umumiyesini ve gerekse şahsi menfaatimizi nazar-ı dikkate almaksızın zahairin müddehir bulunduğu bu kadar iş bilmez kaymakam kazadan alınmalıdır...".

11 “Beypazarı'ndaki çiftliğine muktezi tohumluk müddehir bulunduğu ambarın kaymakam-ı kaza tarafindan mühür altına alınarak ziraatın ta'dile uğradığ Ankara Mebusu Hilmi Bey tarafindan bu kere de beyan ve şikâyet idilmekte olduğundan tebli' sabık veçhile mezkûr çiftliğe muktezi tohumluğun hemen iadesi hususuna kaymakama ihzarı ve tohumluk zahairin mühür altına alınması esbabının inbası ehemmiyetle tebli' olunur". 
gerektiğini bildirmiştir (BOA, DH. ŞFR. 72/37) ${ }^{12}$ Bunda Hilmi Bey’in hem İttihatçı mebuslardan olması hem de Talat Bey tarafından desteklenmesinin etkili olduğu da bir gerçektir. Milli Mücadele'nin başladığ 1 sıralarda Hilmi Bey artık Mebus değildir. Ancak onun arazi ve çiftliklere müdahalesi devam etmiştir. Örneğin, 17 Mayıs 1919 tarihli belgeye göre, Çayırhan ahalisinden Mehmet Dursun ve arkadaşı, Hilmi Bey'in kendilerine ait çiftlik ve meraları gasp ettiği iddiasıyla şikâyetçi olmuşlardır (BOA, DH. İ. UM. EK. 51/96). Ancak bu şikâyetin nasıll sonuçlandığına ilişkin her hangi bir arşiv kaydına rastlanmamıştır.

\section{Sonuç}

Osmanlı coğrafyasının değişik bölgelerinde özellikle de taşrada, arazilerin kullanımı konusunda eşraf ve köylüler arasında zaman zaman gerginlikler ve tartışmalar yaşanmıştır. Bu gibi durumlar, bir yandan asayişin bozulmasına, diğer yandan da hukuki ve ekonomik sorunlara yol açmıştır. Bu cümleden hareketle Çayırhan köyünde yaşanan hadisenin de benzer sonuçlar doğurduğu anlaşılmıştır. Bilhassa şikâyetlerin arttığı dönemlerde merkezi ve yerel yöneticiler de meseleye müdahil olarak sorunun üstesinden gelmeye çalışmışlardır.

II. Meşrutiyetin getirdiği hürriyet ve adalet ilkelerinden yararlanmak isteyen Çayırhan ahalisi, meralarının Hilmi Bey tarafından işgal edildiğini, artık buna bir son verilmesi gerektiğini düşünerek, yerel ve merkezi yönetim nezdinde girişimlerde bulunmuşlardır. Buna karşın Hilmi Bey de söz konusu arazinin tapulu malı olduğunu, köylünün haksız bir şekilde hayvanlarını arazisine soktuklarını iddia etmişlerdir. Bu durum karşısında merkezi ve yerel yönetimin, zaman zaman köylüye hak vermesine rağmen, Hilmi Bey’i haklı gösteren bir tavır sergilediği anlaşılmıştır. Bu bağlamda Hilmi Bey, siyasi nüfuzunu ve ekonomik gücünü hükümet nezdinde kullanarak sorunu büyük ölçüde kendi lehine çözmüştür.

Köylü için ise durum daha farklıdır. Çünkü hayvanlarını otlatacak meralarının olması ekonomik açıdan hayati derecede önemlidir. Çünkü köylü temel ihtiyaçlarını hayvancılıktan karşılamaktadır. Kısacası bu meselede köylünün daha çok zarar gördüğünü söylemek mümkündür.

Sonuç olarak arazi meselesi, sosyal ve ekonomik şartların yol açtığı sosyal bir problemdir. II. Meşrutiyet döneminde problemin çözümü konusunda ciddi adımlar atılmıştır. Ancak atılan bu adımlar problemi çözmede yetersiz kalmıştır.

12 “...Meşrutiyetle idare olunan bir memlekette bilhüküm şunu bunu tevkif ve habs ve mahal-i ahza sevk ve harekata mütecasir olan bir kaymakam bittabi' memuriyeti muhafaza idemez de bu gibi kanunsuz if'alde bulunan memurlarl siz de muhafaza itmezseniz me'haza kaymakamın ahvalı tebdilini istizan suretiyle...”. 


\section{Kaynakça}

\section{Arşiv Belgeleri}

Başbakanlık Osmanlı Arşivi (BOA)

BOA, BEO. 3505/262871.

BOA, BEO. 3521/264074.

BOA, DH. MKT. 2733/278.

BOA, DH. MKT. 2701/95.

BOA, DH. MKT. 2831/37.

BOA, DH. MKT. 2733/28.

BOA, DH. İ. UM. 98/1.

BOA, DH. ŞFR. 72/37.

BOA, DH. İ. UM. EK. 51/96.

\section{Resmi Yayınlar}

MMZC, Cilt 1, Devre 4, İçtima 1, 12 Kanunusani 1336 (1920).

\section{Araştırma ve Tetkik Eserler}

Ahmet Şerif (1325/1909) Anadolu'da Tanin, Tanin Matbaası, İstanbul.

Avcıŏlu, Doğan (2001) Türkiye’nin Düzeni, Tekin Yayınevi, İstanbul.

Aydın, Zeynep (2019) “Cumhuriyet Dönemi Öncesi Köylü Söylemlerin Halkçılık İlkesine Dönüşümü”, Sosyal Bilimler Araştırma Dergisi (KOUSBAD), 9, Bahar ss.27-42.

Ballı, Ergül (2015) “İttihat ve Terakki'nin Tarım ve Toprak Politikası: Aydın Vilayeti Örneği”, Uluslararas1 İttihatçılar ve İttihatçılık Sempozyumu Bildiriler Kitabı, Cilt III, Türk Tarih Kurumu Yayınları, Ankara. ss. 129162.

Bilgen, Bahar (2011) Bilgen, Dönemin Basınına Göre 1919 Seçimleri ve Meclis-i Mebusan'ın Oluşturulması, Yüksek Lisans Tezi, Trakya Üniversitesi Sosyal Bilimler Enstitüsü Tarih Anabilim Dalı, Edirne.

Cem, İsmail (2017) Türkiye'de Geri Kalmışlı̆̆ın Tarihi, 27. Basım, Türkiye İş Bankası Kültür Yayınları, İstanbul.

Güneş, İhsan (1998) Türk Parlamento Tarihi I. ve II. Meşrutiyet, II. Cilt, TBMM Vakfı Yayınları No:15, Ankara.

Haytoğlu, Ercan (2017) "Bekirağa Bölüğünden Malta'ya: Limni Sürgünleri”, Route Educational and Social Science Journal, Volume 4(5), August ss. 98-115.

http://tolunayozakaasml.meb.k12.tr/İcerikler/tarihcemiz4070655.htmlerişimtarihi.27.8.2019.

Keyder, Çağlar ve Tabak, Faruk (2014) Osmanlı'da Toprak Mülkiyeti ve Ticari Tarım, Çev. Zeynep Altok, Tarih Vakfi Yurt Yayınları, İstanbul.

Pamuk, Şevket (2017) Türkiye’nin 200 Yıllık İktisadi Tarihi, 8. Basım, Türkiye İş Bankası Kültür Yayınları, İstanbul.

Şener, Mesut (2001) Nallıhan, MÜ-KA Matbaas1, Ankara.

Toprak, Zafer (2016) Itttihat Terakki ve Cihan Harbi, Kaynak Yayınları, İstanbul.

Tunaya, Tarık Zafer (2011) Türkiye'de Siyasal Partiler: II. Meşrutiyet Dönemi, Cilt I, İletişsim Yayınları, İstanbul.

Yazıcı, Sibel (2018) Osmanlı Meclis-i Mebusanı ve Faaliyetleri (1914-1918), Yayımlanmamış Doktora Tezi, Afyon Kocatepe Üniversitesi, Sosyal Bilimler Enstitüsü Tarih Anabilim Dalı, Afyonkarahisar. 